https://helda.helsinki.fi

\title{
Land, Caste, and Class in rural West Bengal
}

\author{
Roy, Dayabati
}

Palgrave Macmillan

2020-05-29

Roy, D 2020 , Land, Caste, and Class in rural West Bengal . in D K Mishra \& P Nayak (eds)

, Land and Livelihoods in Neoliberal India . Palgrave Macmillan, Singapore , pp. 123-139 . https://doi.org/10.1007/97

http://hdl.handle.net/10138/317005

https://doi.org/10.1007/978-981-15-3511-6_7

Downloaded from Helda, University of Helsinki institutional repository.

This is an electronic reprint of the original article.

This reprint may differ from the original in pagination and typographic detail.

Please cite the original version. 


\title{
Land, Caste and Class in Rural West Bengal
}

\author{
Dayabati Roy 1 禺
}

1 Department of Social and Cultural Anthropology, University of Helsinki, Helsinki, Finland

\begin{abstract}
The abstract is published online only. If you did not include a short abstract for the online version when you submitted the manuscript, the first paragraph or the first 10 lines of the chapter will be displayed here. If possible, please provide us with an informative abstract.
\end{abstract}

By mapping the trajectories of changing dynamics in land relations in both colonial and postcolonial periods in rural West Bengal, this chapter tries to understand the way the land has been determining the issues of the rural economy in the rural hinterland. Based on field-survey data, this chapter argues, first, that the issues of land are shaped through a complex process of dynamic interaction between class, caste and capital. Second, the way the state and its policies do intervene in this complex process in order to shape the issues of land in rural areas has been complicating the matter further by way of privileging the capital and the landed class belonging to higher castes at the expense of the labouring class belonging to subordinate caste groups.

This chapter aims to understand the question of land in rural West Bengal in terms of class and caste. As in the Indian case, Damodaran correctly states, 'economic behaviour is embedded in concrete social relations' (2008: 1), the analysis of land issues in context of caste might yield fruitful results so as to understand the problem more insightfully. As capitalism develops, the scholar observes, 'through a number of business communities rather than an integrated business class' (Ibid.: 2), the issues of land also tend to revolve around more through the dynamics of caste rather than through the dynamics of class. By mapping the trajectories of changing dynamics in land relations in both colonial and postcolonial periods, this chapter explains the way the land has been determining the economy in rural hinterland. Upon examining the field work data gathered in recent period, it reveals, first, that the issues of land are shaped through a complex process of dynamic interaction between class, caste and capital. Second, the way the state and its policies do intervene in this complex process in order to shape the issues of land in rural areas has actually been complicating the matter further by privileging the capital and the landed class belonging to higher castes at expense of the labouring class from subordinate castes. The first section of this chapter explores, on the one hand, the trajectory of transformations in land relations and the role of the upper caste landholding group in shaping the phenomenon of landlessness and, on the other, the implication of policy intervention on the part of the government on all rural classes and groups, particularly on the subordinate land-poor groups. The second section explains the dynamics of ascendancy of the rich peasantry to power in rural West Bengal by means of land ownership and authority over labour, and its politics within the state domain, and beyond, in shaping the condition of labour in the province. The third section examines the way the subordinate labouring class in rural West Bengal do cope with the predicament of their landlessness, and subsequently construct their politics in order to shape, on the one hand, the dynamic consequences of landlessness and on the other, the state policies aiming at generating employment. This chapter concludes that owing to the determinant role of capital whatsoever in agriculture the state of rural economy of India, particularly of West Bengal, has deteriorated leading to transform the class configuration and the rural economy further by means of marketization of farming and other livelihoods. 


\section{Land, Landed Class and Caste}

In its attempt to carry on 'the extraction of a part of the surplus in the form of land revenue' (Chatterjee 1984: 6), the colonial government had undertaken several try-outs in vain before permanently being settled with the Permanent Settlement. Tellingly, the enactment of Permanent Settlement seemed to be the first attempt to make a decree in the 'vast network of laws', as the scholars argue, 'created to legally enshrine specific rights to various groups across the country' (Nielsen and Oskarsson 2016: 69). Most historical narratives written about the experiences of the Permanent Settlement in Bengal reveal more or less the same story that the economy of the province ceased to prosper anymore, rather decaying every now and then, despite the repeated attempts of reviewing the situation and the subsequent policy intervention, be it new or revised form, by the colonial government. Diverse kinds of interests articulated by several numbers of classes, sections and groups thus came to the fore with their own ambiguous rights, identities and demands as consequences of, particularly, the intervention of the organized domain of politics therein. In contrast to the interests of the British colonial state which was imagined as the 'sovereign authority' of all revenues, three categories of main classes made their appearance with their overlapping - sometimes conflictual, sometimes cooperative-demands and interests in the 'political drama' performed in colonial Bengal during the last three decades.

First, the class at the top of the agrarian structure was of the zamindars, the proprietors of the soil. The folks mainly from the upper castes constituted this category by utilizing the opportunities opened by the Permanent Settlement. Apart from the old established landholding families, many others from among the upper castes took the opportunities to become either the 'collectors of revenues' or the privileged 'farmers', and later in due course transformed into a zamindar class. Sarkar (2016) rightly argues that even the businessmen who were once prosperous had become zamindars afterwards. The affluent section of professionals who made their fortunes by way of practicing law and medicines had invested their surplus money either to buy the company's newspapers or the 'zamindari' (Sarkar 2016). He attributes this trend to the lack of interest on the part of Bengali people in business. Sarkar seemed to fail to observe two important reasons why the Bengali people tempted to buy the zamindari. The affluent Bengali persons were tempted to buy the zamindari because, on the one hand, the zamindari was very lucrative, that is, prosperous at that time and, on the other, the business and trades were then progressively turned into loss-making sectors due to the invasion of British imperialist capital. However, Sarkar's narrative depicts one trend clearly that many people, mostly the upper castes, "who were already settled in other sectors had conveniently become the zamindars owing to the facilitating arrangement provided by the Permanent Settlement. But their days were not stable and began to evaporate since particularly the beginning of the twentieth century. Now this upper caste landholding class made a venture towards cities and urban areas to grab all new opportunities in the bureaucracy and trade after the scope of rentier economy began to vanish. This category began to face a two-pronged challenge, on the one hand, from the mass of peasantry and, on the other, from a new class of rich peasant-moneylender-traders. Do we read it on caste term and say that the upper castes began to face challenges both from the lower castes and the middle castes as far as land is concerned?

Second, by utilizing the growing land market, commercial farming and farm-related trading, and, of course, the scope of expansion of agriculture in newer stretches of lands, a new class of people had emerged during the period of late colonialism. This new class can be called as the 'rich peasantmoneylender-trader' class. The people of this class had in the main come from the middle and lower castes as indicated in the studies by Chatterjee $(1984,1987)$, Sanyal (1981) and others and became prosperous gradually through cultivating new land either by purchasing from the debt-trapped peasantry: and from the decaying zamindar class who already began to leave the soil of rural Bengal. Considering the case of West Bengal, the castes like Sadgope, Mahishya, Ugrakshatriya among the middle castes and 
Poundra Kshatriya and Rajbanshi among the scheduled castes (SCs) would constitute this new class. We would also find that a considerable section of Muslim peasants falls in this class inhabited mainly in Bangladesh and in some parts of the northern region of West Bengal. The history of emergence of this class is thus not so old. Hence, the way the castes belonging to this class could shape their trajectory of development in both economic and political terms is very significant to understand the economy and politics of rural West Bengal. The narrative of this class seems also to be important since it has established its 'control over the land and the produce of the peasantry' by 'challenging the erstwhile dominance of the landed proprietor' (Chatterjee 1984: 62).

The third category is the mass of peasantry in rural West Bengal. The people of this category were the worst victims of the breakdown of small peasant economy in Bengal during the period of late colonialism. The peasantry at large who were once mostly the rent payee raiyats turned into marginal in terms of their dismal economic condition. Due to the stress exerted both from the upper caste proprietors and the colonial state, many of them were forced to lose their land and subsequently had become poor peasants. They were turned into either the sharecroppers by losing ownership rights or agricultural labours by losing even the occupancy rights to land. The category of marginal peasants includes the poor peasants, the sharecroppers ${ }^{2}$ and the raiyats (also under-raiyats). A fierce conflict between the upper caste proprietors and the mass of peasantry actually had torn the eastern part of undivided Bengal apart. The lower castes including the middle castes and the scheduled castes as well as the scheduled tribes: (STs) had constituted this category for which most of the government policies are aimed at.

If we take stock of the current status of these classes/castes, we will find an interesting trajectory of class/caste dynamics at the grassroots of Bengal. My ethnographic research (Roy 2013) reveals that most of the local zamindars belonging to the upper castes have eventually fled from their ancestral villages owing to the resistance of the peasantry belonging mainly to the $\mathrm{SC}$ and $\mathrm{ST}$ and also in some occasions to the middle-caste Mahishya under the leadership of Communist Left during the period of 1960s and 1970s (Ibid.). The upper-caste families (here the Kayasthas) have either sold off their land or still have kept it in their possession. In the latter case, they are to engage the sharecroppers for cultivating their land. Most of them have actually taken modern professions and so settled in cities like Kolkata. In my recent survey conducted in 18 villages in 18 districts of West Bengal, I found another interesting phenomenon. Among these 18 villages that had been randomly selected, there is no noticeable trace of the upper castes in as more as 12 villages. This phenomenon is attributable to the proactive roles of the Left Front government and its constitutive parties, to be precise, of the upper castes in implementing and, to some extent, improvising the land reform policies in rural West Bengal. In so doing, the upper castes who had once been the proprietors of land and the perpetrators of rural distress attempted to cut down to size the power of their erstwhile rival, the class of rich peasant-moneylender-traders and thereby establishing their base among the poor peasantry. Do their roles, in that case, indicate any antagonism between two dominant classes, as suggested by the theorists of passive revolution? I mean to say, is this a class contradiction between two classes, that is, the landed elites or rich peasantry, on the one hand, and the bureaucracy, that is, the upper castes, on the other?

Whether or not this effort of the Left Front is a manifestation of perpetual class antagonism between two dominant classes is actually not a factor here to influence the role of the upper castes in policy making on land front. Being the communist (Marxist), the members of these parties could never cross beyond their class boundary and so have hardly left any imprints, in good sense, in rural areas to turn the situation upside down. What these upper castes have done is actually the same as their counterparts in other states intended to do. This is to mean a closer look would easily reveal what the erstwhile proprietors of land have scripted are nothing but the end-products of their caste-class ideologies. The land reform programmes are not meant for the absolute benefit of landless peasants in long term, instead, are devised keeping in mind the case of the labouring class. This means the issues of landlessness are not here 
prioritized. Instead, it seems that the aim of the land reform policies is to at best reduce the rate of poverty. The causes of rural unemployment are reasoned from the standpoint of the upper echelon of the society in class and caste terms, so are the measures of employment generation.

\section{Land, Peasantry and the Dominant Caste}

Notwithstanding the fact that there are various sets of data regarding the evolution of landholding structures in West Bengal, the data about caste-specific landholding structure are really fewer. I would divide the peasantry purposefully into two categories, the rich peasantry and the poor peasantry. Ignoring the consistent debates and confusions regarding different contradictory sets of data, I would reiterate advantageously the conventional supposition that the rich peasantry in general do represent the lower or middle castes particularly in south-western part of Bengal and, partially, two scheduled castes Poundra kshatriya and Rajbanshi in southern part and the northern part of West Bengal respectively. ${ }^{3}$ Needless to say, the poor peasantry would represent the scheduled caste and the scheduled tribe. Long before the penetration of organized state politics, two numerically significant middle castes in southern West Bengal, presently called as Sadgope and Mahishya, ${ }^{4}$ had chosen their route of social mobility in the middle of sixteenth century. Sanyal's magisterial study (1981) has revealed that these castes had first broken away from their parent body known as Gope (a pastoral group) and Chasi Kaibartas (a fishing community) respectively and shifted steadily to agriculture as their new profession. Both the dissident groups, particularly the Sadgope, 'spread over the territory extending between the left bank of Bhagirathi river and the south-western fringe of Bengal, became settled agriculturalist, traders, and officials of the state and of the zamindars' (Ibid.: 45).

Within a short period of time, they had become prosperous cultivators and also substantial landowners and subsequently established themselves as a political power in a vast region. The amalgamation of economic power in terms of land occupation and ownership, and political power helped these castes to achieve cultural superiority by means of 'instituting social services like temple building and offering lucrative grants, such as rent-free land, to the Brahmans'. Subsequently, these factors altogether made Sadgopes and Mahishyas recognized as Nabasakh ${ }^{5}$ castes. Since then, these two castes have been enjoying cultural superiority and posing as dominant castes until recently in the vast tracts of southern West Bengal. Recent ethnographies by the present author on the two castes show the way the Sadgope and the Mahishya do endeavour to continue their domination, cultural, economic and political, in everyday lives of the rural people. The relationship between the dominant castes and the subordinate castes (the Sis) in that region has not only been hierarchical but also a source of severe discrimination in regard to various socioeconomic aspects. The hierarchy or discrimination is such that the people of these dominant middle castes are often called as bhadralok and that of the subordinate castes are considered as chhotoloks.

The economy of this category of rich peasant-moneylenders-traders though been risen steeply in the first half of postcolonial period began to collapse gradually in the recent period. The green revolution technology had brought advantage to this category in the preliminary period, but tended to disadvantage them mainly due to the government's apathy to the distress call of the peasantry. While the peasantry have consistently been distressed due to the determinant role of the unfavourable market, the government instead of protecting them by way of reducing the onslaught of the 'elite' commercial and capitalist classes did aid the latter in their venture of profit accumulation. Victimized both in the field of production and in the field of marketing, the peasantry at large, particularly, the rich peasantry, rarely does embrace a solvent position so that they could pose a challenge to the dominance of the upper castes. Notably, a small group of rich farmers who are having a substantial proportion of land could make their fortune even until the recent period through exploiting the scope of profit making by means of hoarding crops coupled with farming. ${ }^{6}$ However, the rural dominant categories though being in the forefront to manage the electoral support for the urban dominant categories do not assume adequate power and have been 
subordinate in terms of decision making. The rich peasantry has, therefore, been unable to be a part of the coalition of dominant classes, as the theorists of passive revolution argue, as far as the politics of West Bengal is concerned. Rather, as the situation of the state betrays, the upper castes/classes or the bureaucracy, allied with the capitalist classes, have been dominating the politics of West Bengal often at the expense of interests of the peasantry at large. The rich peasantry or 'the dominant castes' have hardly any role in formulation of the policies and acts aimed at all rural classes, including their own class.

The main reason behind this phenomenon seems to be, I argue, the rich peasants' lack in economic and political power even in the field of political institutions and legislatures in the state. Unlike their counterparts in other states, they could not even decide the policies that affect their own issues within and outside the parties and mass organizations since as the leadership of those parties and mass organizations were captured by the upper strata. The political representation of 'agriculturists', the rich peasants in context of West Bengal, however, in Pariliament had increased consistenly during the period of 19521967 while the proportion in the Parliament of the professionals, particularly, the lawyers who were more active in the party during the pre-independence India was in decline. The proportion of the 'agriculturists' in Parliament had increased from 18.3 per cent in 1952 to 36.8 per cent in 1967. If we count it in all party terms, we would see that the proportion has increased from 22.4 per cent in 1952 to 31.1 per cent in 1967. The proportion of agriculturists, in fact, in the Parliament has increased progressively throughout the years. The proportion of the same class in Parliament reached its highest, that is to say, 49.06 per cent in the 12th Parliamentary elections, whereas it is 39 per cent in the last elections (2014) (16th) (Parliament of India website). The increasing proportion of the agriculturalists or the 'large landlords' in Parliament might indicate the fact that the political power of the said class has increased substantially to influence at least numerically the policies and acts meant for rural and agricultural issues. Chatterjee rightly states that the legislature of the states like Punjab and Haryana has, therefore, been witnessing the fiery debates 'on land ceilings or the procurement price of food grains' (1999: 53).

However, the question is whether West Bengal has witnessed any such stormy debate on the issues mentioned above at the political arena, be it the legislature or the political parties. Presumably, the state has barely witnessed such kind of fierce debates in the legislature and in the political parties that initiated on the part of the representatives of rich peasants. Indeed, the list of the MPs elected in West Bengal, whatever their party identities may be, clearly reveals that not even a single MP in West Bengal belongs to the rich peasantry at least as far as their profession is concerned. It might be the case that at least a few of the MPs though have been elected from seats of the rural region and belonging to the rich peasantry class have preferred to mention business or social work as their profession to farming whatever the reasons may be. In no case, however, the representation of the rich peasants in the political arena doesn't count much, so does the issue of rich peasants. During my field work in the state, I found that the rich peasants, especially, in the Hooghly district instantly vented their grievances against the governments for its failure to aid them in their acute distress. One rich farmer asserts, 'we don't have our own party or platform on behalf of which we can negotiate our issues or requirements with the government. In other states, the farmers are organized and so do succeed to garner the benefit in a united way in regard to farming. For instance, the farmers of the other states have largely benefited by way of subsidization in tariff for electric pumps'. It is easily discernible at this stage how far the rich farmers could get capacity to influence the governmental policies, especially the policies aimed at land issues in rural areas, while they themselves are in want of scope to place their own demands on the government.

The rich peasants are, however, not in need of scope to exert their influence in shaping the nature of outcomes of the governmental policies when the latter are moving downwards for implementation to the rural grassroots. The classes that are dominant in the rural West Bengal do then become the custodians of governmental policies and make every effort to determine its fate, of course in collaborating with the upper castes-classes who are living in the cities. The top political leaders as well as the bureaucracy most 
of whom belonging to the upper castes-class are seemingly agreed at least to some extent to compromise on some issues proposed by the rural dominant class. Presumably, due to this very reason, the Left Front leaders, as we have seen, who were very active in formulating the MGNREGA at the Centre had visibly been reluctant at the initial period to implement this act in the state in 2006. The rural leaders of both of the party and the panchayat especially those belonging to the landowning higher castes do usually interpret their tasks of implementing the act in terms of supplicant modality, particularly if and when the benefit seekers do belong to the landless subordinate groups and the vice versa. As hordes of uncertainty prevailed in every step of implementation of the programme ranging from creating of work to payment of wages, the beneficiaries are seen to be immensely dependent on the leaders of the respective fields and so eventually become supplicant for even small things to be done. However, castes seem to provide more signifying terms than class through which the social relations and the subsequent supplicant modality are perceived.

\section{Landlessness, Employment and the Subordinate Castes}

It has been described the way the category of peasants most of whom belonging to the lower castes particularly the scheduled castes in West Bengal have become increasingly poor and so be the target of various governmental policies ever since even the colonial period. The poor peasantry, that is, the landless peasants, the sharecroppers and the marginal land owners, could hardly improve considerably their position throughout these years. Many people from this category seem to still remain unemployed or underemployed during most part of the year all over the state. If we try to gauge the extent of their predicament in terms of poverty discourse, it may appear that their economic condition has improved. But, the ethnographic enquiry into their joblessness would soon make us disillusioned, and we would find that a particular section of people in every village is consistently in search of work. This is the section which constitutes the poor peasantry in West Bengal. This is the section which neither flourishes in economic terms, nor 'advances' in social position. This is the section in the rural areas which identifies that the land and land relations are the basis of all their problems in regard to work. History shows the way in which this section of peasantry would mobilize itself in the late colonial period under the banner of political parties taking the issues of land. However, it has also elucidated that the penetration of the state in matter of land and land relations has only complicated the issues by rendering a section of peasantry increasingly vulnerable by way of making them either landless or sharecropper.

From the Permanent Settlement to assorted kinds of Land Reform Act passed in postcolonial India including the recent tenancy reforms initiated by the West Bengal government during the end of 1970s, as my recent work shows (Roy 2018), the predicament of the people of this group has essentially hardly changed. The people of this section who are enormously variegated in terms of proprietary and occupancy rights in question of land have administratively been identified since long as various names, for example, the raiyats, under-raiyats, tenants, sharecroppers, bargadars and so on, while the forms of precarity that are associated with their livelihoods have remained the same. A longitudinal survey of the policies might reveal that most of the policies and the acts in rural areas are meant for the benefit of this section of people. This is the reason why this section of the people is the most politicized population in India. Why does the politics of the state fail to deliver justice to this section of people notwithstanding its consistent efforts by way of its policy intervention into the latter? The belief that the state is neutral and supposed to be maintaining a balance among various classes and categories that existed at a particular point of time seems to have been a real culprit in making our understanding blurred. How does the state take a neutral position and maintain a balance among various classes in the societies which have already been skewed towards the propertied classes? Does not the state require having a labouring class skew in order to establish some forms of equality?

It is, of course, undeniable that the characters of the classes which constitute the power have great roles in 
determining and shaping the nature of policies and its implementation at the grassroots. However, I would argue, what is more significant is the guiding ideology which does prompt the ruling classes to construct their respective policies. The ideology decides the fate of capital and its accumulation in a particular society. Take the land reform acts and policies, for instance, to understand its impacts on the landless peasants of West Bengal in employment terms. During the period of colonialism, the Permanent Settlement which was marked as the beginning of colonial policy regime in regard to land was just the sheer reflection of the British capitalist interest to extract the profit from land in terms of revenues. The subsequent land policies or acts, for instance, the Bengal Tenancy Act, which have been followed since were of no exception. It may appear that those policies were having a marginal peasant category skew. But a thorough historical analysis would prove that these were aimed at only to maintain the small peasant economy for its uninterrupted exploitation in Bengal in longer term. All these policies, however, were doomed to failure due mainly to the growing class contradiction in society and eventually culminated in the recommendation of Floud Commission. The land reform acts that were undertaken in postcolonial India are nothing but a reproduction of the Floud Commission which recommends, on the one hand, the withdrawal of intermediaries and the direct relation between the state and tenants and on the other hand, the landlords' keeping hold of land though to a certain amount and the grant of compensation whatsoever for departure from the zamindari. The first part of the recommendation is nothing new but the imitation of indigenous tradition under which the peasants of Bengal had remained for long. The second part of the recommendation is definitely drafted with an aim to benefit the landlord class. But, needless to say, it was meant mainly for the enhancement of capital.

Whatever it may be, I have attempted to explain the impact of implementation of the land reform acts on the peasants of two different settings of West Bengal which are distinct from each other not only in terms of its geography and proximity to city, but also of its ethnographic components. The northern part and the southern part of West Bengal are these two distinct regions. The landless peasants belonging to the ST: community who were at the forefront of the land struggles led by the Communists in the northern part could hardly manage to get any land vested and distributed by the party. There exists a sense of latent discontent among the landless labourers as most of the land that were seized from the jotedars families had been distributed among the ardent followers of the top party leaders. ${ }^{10}$ On the contrary, the erstwhile jotedars families could retain most part of their lands and still own around 100 bighas of land as informed by the present member of the panchayat. Most of them are to supplement their income from agriculture, be it as cultivator or as day labourer. The villagers get lots of scope to involve themselves in various odd jobs owing to the village's proximity to the city. Agriculture is not considered usually gainful by most of the landowners due to the very fact that most of the lands are not multi-crop and well-irrigated. The green revolution technology seems to have not been useful in this particular area. Rather, as informed, land inside the village has often been traded with the outsiders at soaring price, thanks to the rapid urbanization. It transpires the fact that the land is not as useful in terms of agriculture as it is in terms of trade. Therefore, despite the concentration of land in few hands, agriculture did not grow with reference to productivity of land, and the capitalist expansion in agriculture too is somewhat moderate. The surplus from land has not been accumulated in such a way that the class configuration would change. The employment or livelihoods of most of the families irrespective of class and communities are not fully based on the village economy with scores of people among them increasingly fleeing the village for making both ends meet.

The out-migration of the people from the villages in the southern part of the state, however, as mentioned earlier, is no less important to understand the recent crisis in work in rural areas. But the issues of land and agriculture in this region seem to transpire a different story. The $\mathrm{SC}$ and $\mathrm{ST}$ families constitute, not surprisingly, the category of landless. Interestingly, analysed separately, the $\mathrm{SC}$ families do hardly have land due only to the reason that they didn't obtain almost any patta land from the then party in power. On the contrary, some $\mathrm{ST}$ families being the passionate loyal to the erstwhile ruling party could manage to 
obtain 0.25 bigha of land each on an average. The empirical findings transpire the fact that the village economy which is characterized by farm-based work and agriculture has been viable by way of providing employment for almost all villagers as main source of income. Non-farm works whatsoever are being created at the margin even if sporadically have also been sustained by the activities associated with farming. The landowners, particularly the substantial landowners, seem to have been prospering the most by diversifying their professions into a number of other fields based mainly on sustainable agriculture thanks to private irrigation initiatives. ${ }^{11}$ Besides, these farmers do also enjoy the advantage of investing the incomes from other occupations, be it the business and the service, in farming only in order to make it more profitable. The class relations in terms of land and other occupations are sharply reflected in the village reality.

Interestingly, the agricultural wages prevalent in both two sets of villages are lower to a great extent than the wages stipulated by the government. ${ }^{12}$ The question arises that in what way the rural labourers would experience the indirect outcomes from the MGNREGA when they are not even drawing the minimum wages prescribed by the government. What has been possible, as Carswell and Neve (2014) observed, in Tiruppur district of Tamil Nadu that the rural poor could experience some real gains of MGNREGA is actually still a dream to the rural labourers of West Bengal. Unlike their counterparts in Tamil Nadu, the labourers in West Bengal do hardly experience 'indirect outcomes include the availability of an employment alternative, the increase in agricultural wages' and 'the improvements in labourers' bargaining power vis-à-vis employers' (Ibid.: 583). This is due to not only the fact that the programmes under the MGNREGA are not effective in terms of both creation of work and regular payment of wages, but also the very reason that the work under this act do not create a pressure on the supply chain of labourpool as mentioned earlier. Now let's examine the outcomes of implementation of the provisions to benefit directly the marginal peasants, that is, the sharecroppers as well as the so-called deprived sections like the $\mathrm{SC}$ and $\mathrm{ST}$ people in terms of creating durable assets in the context of caste and class. It is often thought that the revisions of the MGNREGA by way of notifications issued by the government are skewed towards the interests of the labouring class and of the deprived social categories. It has no doubt, however, that the likelihood of implementation of the provisions which are thought to be skewed towards the interests of the labouring class and of the deprived social categories is often curtailed in the villages wherein the dominant castes and the substantial landowners are in the helm of local power. As far as the prevailing caste-class dynamics in West Bengal is concerned, it seems to be not an easygoing task that the party and panchayat leaders, the land owners belonging to the higher castes, would follow the order of the governments and implement immediately.

The class seems also to be a factor in carrying out the provisions meant for a definite class. Would the people of the landholding class who require the agricultural labourers to cultivate their lands pay attention to implement the provisions that would benefit their labourers? The findings reveal that despite the fact that the landholding class and the landless class, the would-be beneficiaries, belong to the same $\mathrm{SC}$ categories, these provisions have hardly been followed. In the south-western districts, a renowned NGO has been devising projects of creating water harvesters on the lands of the $\mathrm{SC}$ and $\mathrm{ST}$ people mainly for the purpose of irrigation. These water harvesters, locally called as Hapa, are obviously beneficial and 'can bring substantial changes' to the livelihoods of the hapa-owners (Banerjee 2012: 11). ${ }^{13}$ The acute scarcity of water for irrigation debars even the landowners to make a decent livelihood in these districts. By providing the irrigation water for agriculture, these water harvesters no doubt are changing the lives of the landowners. Various cost-benefit analyses show the way their entrepreneurship has increased and they are cultivating various crops 'with an eye to the market'. Whether or not these water harvesters have changed their lives once for all, however, would remain as a question for the future. The question which probably concerns us more is about whether the lives of the landless labourers are also changing accordingly after the construction of these water harvesters? The answers are, I suppose, mostly negative. Initially, the labourers got work for some days whatsoever under the scheme of 'making harvesters' as part of 
MGNREGA, but the creation of jobs didn't continue for long. After a while, they would remain again unemployed as usual. One budding phenomenon has rather increasingly been prominent at the grassroots that the small and marginal cultivators who have in their possession the newly made water harvesters are accumulating profits accrued from the land by way of high yielding of land, multi-crop cultivation and, above all, multi-uses of water from the harvesters. They even try to make profit by selling irrigation water to other owner cultivators, be it the sharecroppers or the landowners. Has there been a contrast class relation emerging at the margin among the marginal peasants most of whom are belonging to the same community? The classes are going to be distinct, but it remains to be seen how sharp they are.

The issues of land and work in rural areas are thus intensely rooted in the dynamic relations of castes and classes. We must have to analyse the intricate relations among various castes and classes, if we endeavour to understand the problem of poverty and unemployment in India. The capitalist transformations at the rural hinterland since the early time under the British colonial rule have, of course, problematized the domain of land and work in India to a great extent. The roles of the state, both the colonial and the postcolonial, in shaping the nature of the issues associated with land are also of immense importance. By exploring the nature of capitalist transformation in the domain of land and work at the rural hinterland of West Bengal through a comparative analysis of different zones which are distinct from each other in terms of not only its proximity to city but also its ethnographic components, this chapter reveals that the nature of land relations and work varies greatly on the basis of specificities of a particular social reality. The rural India has changed enormously since the liberalization of its economy in late 1980s, and the dynamic condition of work including its security has subsequently taken new forms all over the country. Rural West Bengal is no exception. While the 'determinant' role of capital whatsoever leads to transform the class configuration and the economy in rural areas by means of marketization of farming and other occupations, the government's attempts aimed at supporting the rural labour through particularly the MGNREGA do complicate the issue further. The question that arises is the way in which the contemporary rural is changing as a result of marketization and, similarly, in what way do the politics of rural people shape the outcomes of capitalist transformation. How do the rural people across class, caste, religion and gender shape the economic restructuring of global capital in their lives and livelihoods? By examining these questions critically, this chapter reveals that while the economic transformations do impact differently on different classes of people in terms of land and work, a specific local setting having particular forms of inequalities engender distinct capitalist dynamics.

\section{References}

Banerjee, P. S. (2012). Impact Study of Hapa and Its Multiple Uses in Bankura District. Colombo: International Water Management Institute (IWMI).

Carswell, G., \& De Neve, G. (2014). MGNREGA in Tamil Nadu: A Story of Success and Transformation? Journal of Agrarian Change, 14(4), 564-585. https://doi.org/10.1111/joac.12054.

Chatterjee, P. (1984). Bengal, 1920-1947, the Land Question. Calcutta: K.P. Bagchi and co.

Chatterjee, P. (1999). The Partha Chatterjee Omnibus. Delhi: Oxford University Press.

Damodaran, H. (2008). Indian's New Capitalists: Caste, Business, and Industries in a Modern Nation. Basingstoke: Palgrave Macmillan.

Nielsen, K. B., \& Oskarsson, P. (2016). Development Deadlocks of the New Indian State. Economic and 
Political Weekly, 51(4), 67-69.

Roy, D. (2013). Rural Politics India: Political Stratification and Governance in West Bengal. Delhi: Cambridge University Press.

Roy, D. (2018). Employment, Poverty and Rights in India. Abingdon: Routledge.

Sanyal, H. (1981). Social Mobility in Bengal. Calcutta: Papyrus.

Sarkar, B. K. (2016). Banglar Jamidar (In Bengali) [Landlords of Bangla]. Kolkata: Serbian.

The list of zamindars provided by Sarkar entails that many of them actually belonged to the upper castes.

2 The sharecroppers include the bhagchasi, bargadar or adhiar.

In both the cases, a proportion though being very small from Poundra Kshatrya and Rajbanshi is having large amount of landed property and locally dominant. The social, political and economic dominance of this section of people are huge.

Two other castes, namely Tili and Bhumij-Kshatriyas, had taken successfully the same way of social mobility movements.

5 The Nabasakh rank in the caste hierarchy in Bengal is said to have been formed of nine (nava) branches (sakha) of the clean sudras. But its rank now includes 14 castes, in some places in Bengal even 15 or 16 castes. In general social estimation, the nabasakh castes remain below the Baidyas and Kayasthas as the latter are mostly land owners and professionals, while the Nabasakh castes are traditionally and predominantly artisans, agriculturalists and traders. But like these two castes, they enjoy the right to offer drinking water to the Brahmans. Hence they are jalacharaniya, that is, water (jal) served by them is acceptable to the Brahmans. The nabasakh castes are entitled to receive the services of the clean Brahmans in their religious functions. (Sanyal 1981: 39-41).

6 It is true, as Chatterjee argues, 'whatever growth did occur was for a limited period, in specific regions and among owners of large holding' (1999: 53).

7 Downloadable at www.parliamentofindia.nic.in/jpi/March2000/CHAP-5htm

8 In 1999, the NSSO report says, only 12 per cent of all pump sets used by the farmers in West Bengal are electrified.

${ }^{9}$ This category includes most obviously the ST and the lower castes among the Muslims. As they are beyond our purvew discussion, I would skip their cause.

${ }_{10}^{10}$ One respondent informs that the ardent followers of the top leaders of the CPI (M) party live in the neighbouring villages.

11 Boro paddy and potato are grown extensively by the farmers as commercial crops. The Shallow Tube Well (STW)s and Deep

Tube Well (DTW)s are used for irrigation purpose if or when necessary.

${ }^{12}$ The men labourers earn around Rs. 150.00 with some food as breakfast in the morning as per day wages whereas the wage stipulated by the state government of West Bengal was Rs. 206 with food per day during the same period.

${ }^{13}$ This is an 'Impact study of Hapa and its multiple uses in Bankura district'. The study has been conducted in Hirbandh block, Bankura, in the year 2012. The report of the study is downloadable at www.iwmi.cgir.org. Delhi. 